\title{
Chromosome number, karyotype morphology, heterochromatin distribution and nuclear DNA content of some talitroidean amphipods (Crustacea: Gammaridea)
}

\author{
Angelo LIBERTINI, RenAta TRISOLINI and MASSIMILIANo RAMPIN \\ Consiglio Nazionale delle Ricerche, Istituto di Scienze Marine, Sezione di Venezia, Riva 7 Martiri 1364/a, 30122 Venezia, Italy; \\ e-mails: angelo.libertini@ismar.cnr.it; massimiliano.rampin@ismar.cnr.it
}

Key words. Amphipoda, cytogenetics, karyotype evolution, genome size, terrestrial life, adaptation

\begin{abstract}
Chromosome number, karyotype formula, C-banding pattern, genome size and DNA base composition were studied in three species of Hyalidae and seven species of Talitridae. A karyotype of 25 chromosome pairs, with median centromeres (FN $=$ 100), was found in all the species of Talitridae analysed and Apohyale prevostii. Genome size (C-value) varies among Talitrida from $0.94 \mathrm{pg}$ in Apohyale crassipes to $2.81 \mathrm{pg}$ in Orchestia gammarellus, and the percentage of AT-DNA in the whole genome ranges from $56.12 \%$ in $A$. crassipes to $68.17 \%$ in Sardorchestia pelecaniformis. In comparison with Hyalidae, Talitridae show more uniformity in chromosome number and karyotype formula, and have larger genomes. There is a direct correlation between total DNA content and the amount of C-heterochromatic DNA. The cytogenetical data on Talitrida were compared from a phylogenetic and an evolutional point of view. The increase in genome size during the evolution of the Talitrida possibly had a role in their adaptation to supralittoral life and extreme subaerial conditions.
\end{abstract}

\section{INTRODUCTION}

Systematics of talitroidean amphipods has been revised by many authors in recent years (see references in Serejo, 2004) on the base of phylogenetic analyses of morphological and ecological characters. In a recent classification, based on a cladistic analysis (Serejo, 2004), talitroideans are ranked as an infraorder (Talitrida) including 3 superfamilies, 11 families, 96 genera and about 400 species.

As stressed by Farris (1978) and Dobigny et al. (2004) cytogenetical studies may provide additional characters for phylogenetic tree construction. Unfortunately, our cytogenetical knowledge of Talitrida, and Amphipoda, is rudimentary. For Talidrida, haploid and/or diploid chromosome number is known for 8 species (4 of Hyalidae and 4 of Talitridae), karyotype for only 3 species (all Hyalidae), and there is no data on heterochromatin distribution and nuclear DNA content (Poisson \& Le Calvez, 1948; Le Calvez \& Certain, 1951; Bachmann \& Rheinsmith, 1973; Coleman, 1994; Libertini \& Krapp-Schickel, 2000). The present study aims to improve our knowledge of the cytogenetics of both Hyalidae and Talitridae by providing original data on some karyological parameters.

\section{MATERIAL AND METHODS}

Seven species of Talitridae and three of Hyalidae were studied. Scientific names, authors' names, year of description and geographical origins of these species are listed in Table 1. Species and genera names of Hyalidae follow Bousfield \& Hendrycks (2002). Some authors (Stephensen, 1940; Ingólfsson, 1977) ascribe the hyalid inhabiting the intertidal zone along the Iceland coast to Apohyale nilssonii (Rathke, 1843), which is considered to be a junior synonym of Apohyale prevostii (Milne Edwards, 1830) (Barnard et al., 1991; Bousfield \& Hendrycks,
2002). Systematics of Talitridae takes into consideration the nomenclature recently proposed by Tafani et al. (2004) for the Mediterranean sandhoppers previously assigned to the genus Talorchestia (sensu lato).

The populations from Lake Garda and other North European sites, previously reported as Orchestia cavimana Heller, 1865, are presently under systematic review (Ketmaier et al., 2003; Ruffo, pers. comm.) and will be ascribed to a new species (Orchestia garbinii sp. n.) genetically close to the typical $O$. cavimana (De Matthaeis \& Ruffo, pers. comm.). Therefore, the Lake Garda population is herein named as Orchestia prope cavimana.

Chromosome preparations were made using the hot-dry method applied to early embryos, or alternatively male gonads, as outlined by Libertini et al. (2000). Slides were examined using a JenaMed 2 microscope (Carl Zeiss Jena, Germany) equipped with a black and white CCD camera. At least 30 chromosome plates for each species were counted to determine the chromosome numbers (haploid and/or diploid). Karyotypes were arranged according to chromosome size measured on digitalised pictures of metaphase plates, using the Corel Photo-Paint image program. Chromosome classification is according to Levan et al. (1964) and the centromeric index was evaluated using the method proposed by Naranjo et al. (1983). At least three Giemsa stained karyograms were examined for each species. C-banding of chromosomes was revealed by treating them with barium hydroxide and staining with Giemsa following the method used by Sumner (1972), but reducing the treatment with alkaline solution to 30-60 s (Libertini et al., 2000).

Genome size (GS) and nuclear AT-DNA content (AT-DNA) were evaluated using flow cytometry on amphipod cell suspensions of preferably late embryos or pooled internal organs of adult specimens. Cell suspensions were prepared following Libertini et al. (2000). A xenon-mercury lamp cytometer (BRYTE-HS, Bio-Rad Laboratories Inc., Hercules, California, USA) was used. Peripheral blood erythrocytes from chicken (2C $\mathrm{GS}=2.50 \mathrm{pg}, 2 \mathrm{C}$ AT-DNA $=1.39 \mathrm{pg})$ (Tiersch et al., 1989; 
TABLE 1. List of the species of the talitroidean amphipods analysed.

\begin{tabular}{lll}
\hline Species & Author / Year & Geographical origin \\
\hline FAMILY TALITRIDAE & & \\
$\begin{array}{l}\text { Orchestia prope cavimana } \\
\text { Orchestia gammarellus }\end{array}$ & Heller, 1865 & Lake Garda, NE Italy \\
Orchestia mediterranea & (Pallas, 1766) & Venice Lagoon, NE Italy \\
Orchestia montagui & A. Costa, 1853 & Venice Lagoon, NE Italy \\
Platorchestia platensis & Audouin, 1826 & Venice Lagoon, NE Italy \\
Sardorchestia pelecaniformis & Kroyer, 1845 & Venice Lagoon, NE Italy \\
Talitrus saltator & (Bellan-Santini \& Ruffo, 1986) & Sardinia, Italy \\
FAMILY HyaLIDAE & (Montagu, 1808) & Crete, Greece'; Sardinia, Italy ${ }^{2}$ \\
Apohyale crassipes & & \\
Apohyale prevostii & (Heller, 1866) & Venice Lagoon, NE Italy \\
Protohyale (Protohyale) schmidti & (H. Milne Edwards, 1830) & SW Coast, Iceland \\
\hline
\end{tabular}

${ }^{1}$ material for chromosome analyses; ${ }^{2}$ material for DNA analyses.

Ronchetti et al., 1995) were added to amphipod cell suspensions as an internal standard. The nuclei were stained with propidium iodide and Hoechst 33258 or DAPI for GS and AT-DNA evaluation, respectively. For each sample at least 3,000 cells were examined and the DNA index (mean channel number of the $G_{1} / G_{0}$ peak of the talitrid cells over the mean channel number of the $\mathrm{G}_{1} / \mathrm{G}_{0}$ peak of the chicken cells) was evaluated after elaboration of the fluorescence data by means of the Modfit software (Verity Software House Inc., Topsham, Maine, USA). The average DNA indices of the samples, multiplied by half of the DNA content of the standard, gave the haploid value (C-value) assigned to the each species (data are reported as mean $\pm \mathrm{SD})$.

\section{RESULTS AND DISCUSSION}

\section{Chromosome number and karyotype}

The diploid chromosome number $2 \mathrm{n}=50$ and a karyotype made up of 25 pairs of median centromere chromosomes (metacentrics or submetacentrics) corresponding to a fundamental number of chromosome arms $\mathrm{FN}=100$, were found in all of the eight talitroidean species analysed (Fig. 1 and Table 2). The finding of $2 n=50$ chromosomes on the mitotic plates of Orchestia prope cavimana and Sardorchestia pelecaniformis was confirmed by the observation of 25 chiasmatic bivalents in spermatocytal metaphase I plates of these two species (Fig. 2A, B; Table 2). Among talitroids, the haploid chromosome number $n$ $=25$ is reported by other authors for O. gammarellus, $O$. mediterranea, Desayesorchestia deshayesii, Talitrus saltator and A. prevostii (Poisson \& Le Calvez, 1948; Le Calvez \& Certain, 1951; Coleman, 1994) and 2n data herein presented confirm this. All the Talitridae so far studied are endowed with the same karyotype (50 m-sm; $\mathrm{FN}=100$ ), while the Hyalidae show more variability in chromosome number and karyotype symmetry (Table 2).

\section{Constitutive heterochromatin}

In $A$. crassipes (Fig. 2C), about half of the chromosomes have a tiny heterochromatic block located in the centromeric area (C-band + in Table 2$)$. In all the Talitridae (Fig. 2D-I;) paracentromeric constitutive heterochromatin is present in nearly all the chromosomes. In $O$. gammarellus, $O$. mediterranea, and $T$. saltator C-bands appear as long, thick and intensely stained bodies, sometimes occupying large segments of chromosomes (Fig.
2E, F, and I; C-band +++ in Table 2). Otherwise, as in $O$. prope cavimana, O. montagui, and $P$. platensis, heterochromatic blocks are generally smaller than in the other three talitridae (Fig. 2D, G, and H; C-band ++ in Table 2).

\section{Genome size and DNA base composition}

GS, AT-DNA, and percentage of AT-DNA (AT \%) in the whole genome of the talitroids analysed in this study are given in the first three columns of Table 2. GS (C-value) varies from $1.71 \mathrm{pg}$ in $O$. montagui to $2.81 \mathrm{pg}$ in $O$. gammarellus among the Talitridae, and from 0.94 pg in $A$. crassipes to $1.89 \mathrm{pg}$ in $A$. prevostii among the Hyalidae. On the whole Hyalidae have a lower GS than Talitridae. Among Talitridae, six species out of seven (belonging to 5 genera) have a similar DNA base composition, expressed as AT $\%$, with values around $65 \%$, the only exception is O. montagui. Present data of the AT\% in Hyalidae is too scanty to highlight a trend. The only other amphipod studied for DNA base composition is the Ischyroceridae Jassa marmorata Holmes, 1903 in which the AT \% was 28.85 (Libertini et al., 2000). Talitroideans have larger values (range 56.12-68.17\%) and, therefore, a greater variability in this parameter is expected within the order Amphipoda. A. prevostii is characterized by GS and AT $\%$ values comparable to those of Talitridae.

\section{General remarks}

When cytogenetical data are compared, Talitridae are more uniform than Hyalidae in chromosome number, karyotype morphology (FN) and probably also DNA base composition. Chromosome number differentiates the three hyalid genera Apohyale, Parhyale, and Protohyale, with each genus having a particular value $(2 \mathrm{n}=50,2 \mathrm{n}=$ $48,2 \mathrm{n}=22$, respectively, see Table 2). Apohyale and Parhyale are more closely related to one another than to Protohyale, according to Bousfield \& Hendrycks (2002), and have similar chromosome numbers. Therefore, chromosome number is a potential (cytogenetical) character useful in phylogenetic reconstruction. Nevertheless, further karyotypical analyses are needed to confirm this.

Among talitroideans variability in genome size and C-heterochromatin distribution pattern occurs: these two parameters seem to be directly related since species with a high GS also have large and widely distributed paracen- 


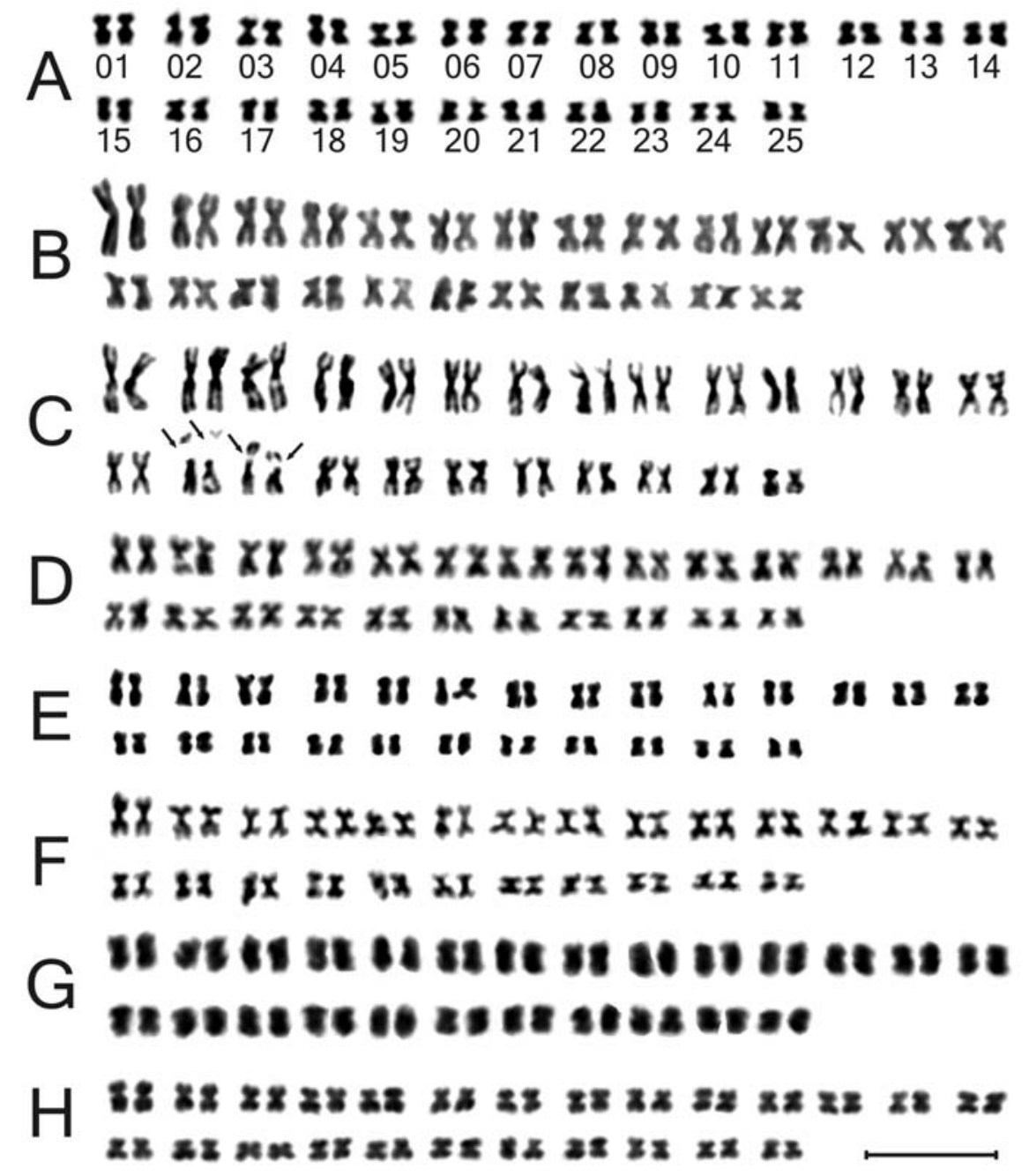

Fig. 1. Giemsa stained karyotypes. A - Orchestia prope cavimana; B - O. gammarellus; C - O. mediterranea; D - O. montagui; E - Platorchestia platensis; F - Talitrus saltator; G - Sardorchestia pelecaniformis; $\mathrm{H}$ - Apohyale prevostii. Arrows indicate secondary constrictions. Scale bar $=10 \mu \mathrm{m}$.

TABLE 2. C-values in picograms of genome size (GS) and nuclear AT-DNA content (AT-DNA), percentage of AT-DNA in the whole genome (AT \%), dimension and distribution of constitutive heterochromatin (C-band), haploid (n) and diploid (2n) chromosome numbers, karyotype and describing references, respectively, for some talitroidean amphipods.

\begin{tabular}{|c|c|c|c|c|c|c|c|c|}
\hline Species & GS (pg) & AT-DNA (pg) & AT $(\%)$ & C-band & $\mathrm{n}$ & $2 n$ & Karyotype & Reference \\
\hline \multicolumn{9}{|l|}{ FAMILY TALITRIDAE } \\
\hline Desayesorchestia deshayesii & & & & & 25 & & & $\mathrm{~b}$ \\
\hline Orchestia prope cavimana & $1.77 \pm 0.044$ & $1.18 \pm 0.010$ & 66.46 & ++ & 25 & 50 & 25 (m-sm) & $\mathrm{pp}$ \\
\hline Orchestia gammarellus & $2.81 \pm 0.028$ & $1.82 \pm 0.030$ & 64.54 & +++ & 25 & 50 & $25(\mathrm{~m}-\mathrm{sm})$ & a, pp \\
\hline Orchestia mediterranea & $2.28 \pm 0.039$ & $1.51 \pm 0.050$ & 66.19 & +++ & 25 & 50 & 25 (m-sm) & $\mathrm{b}, \mathrm{pp}$ \\
\hline Orchestia montagui & $1.71 \pm 0.033$ & $1.00 \pm 0.038$ & 58.73 & ++ & & 50 & 25 (m-sm) & $\mathrm{pp}$ \\
\hline Platorchestia platensis & $1.86 \pm 0.027$ & $1.26 \pm 0.041$ & 67.92 & ++ & & 50 & $25(\mathrm{~m}-\mathrm{sm})$ & $\mathrm{pp}$ \\
\hline Sardorchestia pelecaniformis & $2.68 \pm 0.023$ & $1.83 \pm 0.035$ & 68.17 & & 25 & 50 & $25(\mathrm{~m}-\mathrm{sm})$ & $\mathrm{pp}$ \\
\hline Talitrus saltator & $2.20 \pm 0.069$ & $1.43 \pm 0.023$ & 64.98 & +++ & 25 & 50 & 25 (m-sm) & $\mathrm{a}, \mathrm{pp}$ \\
\hline \multicolumn{9}{|l|}{ FAMILY HyalidaE } \\
\hline Apohyale crassipes & $0.94 \pm 0.026$ & $0.53 \pm 0.014$ & 56.12 & + & & 50 & $19(\mathrm{~m}-\mathrm{sm})+5 \mathrm{st}+1 \mathrm{a}$ & $d$ \\
\hline Apohyale prevostii & $1.89 \pm 0.046$ & $1.19 \pm 0.019$ & 63.22 & & 25 & 50 & 25 (m-sm) & $\mathrm{c}, \mathrm{pp}$ \\
\hline Protohyale (Protohyale) schmidti & $1.05 \pm 0.014$ & & & & & 22 & $11(\mathrm{~m}-\mathrm{sm})$ & d \\
\hline Parhyale aquilina & & & & & & 48 & $24(\mathrm{~m}-\mathrm{sm})$ & $\mathrm{d}$ \\
\hline
\end{tabular}

C-band - coding for C-band is described in the text. Karyotype - (m-sm), meta-submetacentric; st - subtelocentric; a - acrocentric. Reference coding: a - Poisson \& Le Calvez, 1948; b - Le Calvez \& Certain, 1951; c - Coleman, 1994; d - Libertini \& KrappSchickel, 2000; pp - present paper. 

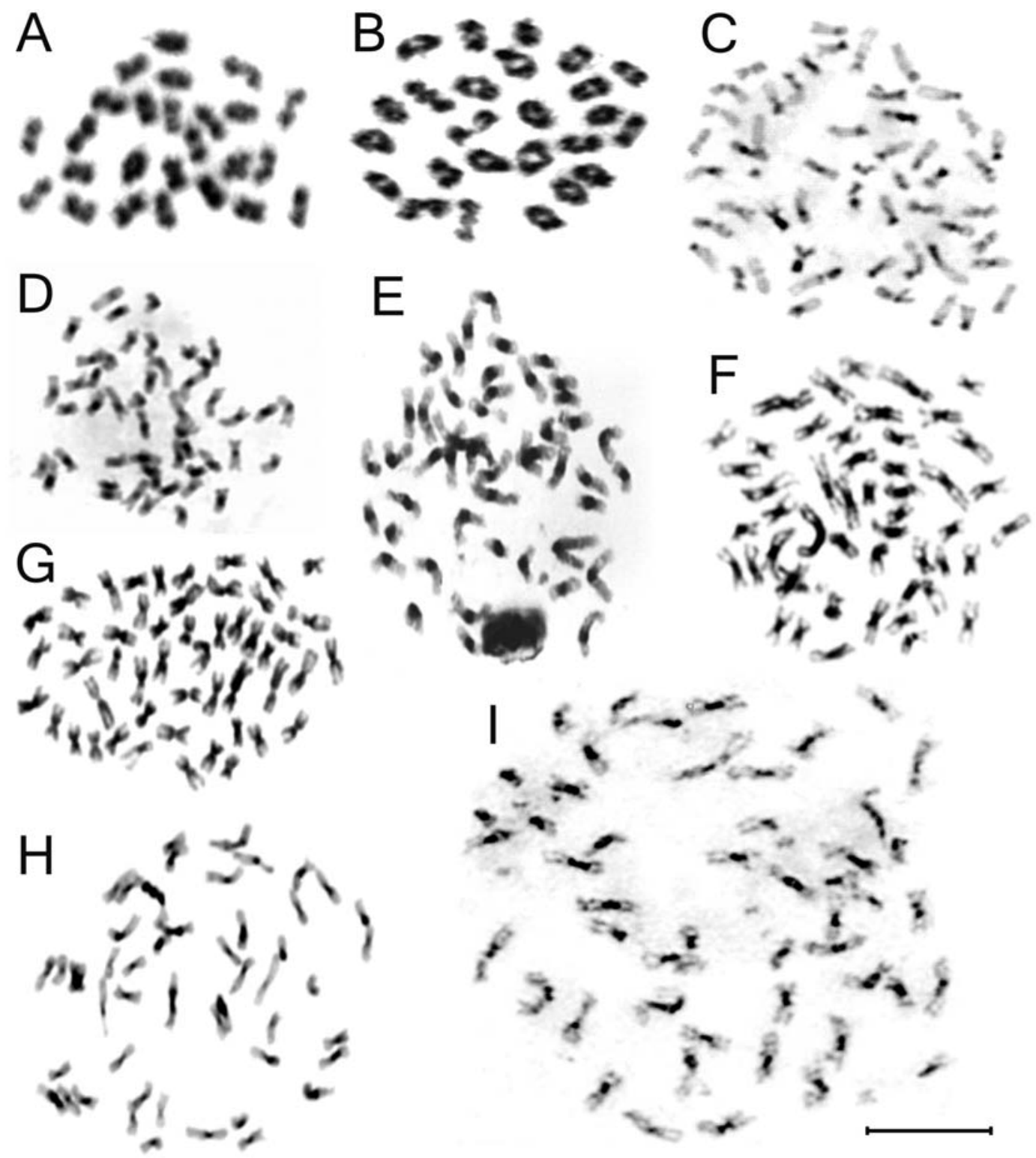

Fig. 2. A-B - Spermatocytal first metaphase bivalent chromosomes. C-I - C-banded mitotic metaphase. A, D - O. prope cavimana; $\mathrm{B}-\mathrm{S}$. pelecaniformis; $\mathrm{C}-A$. crassipes; $\mathrm{E}-$ O. gammarellus; $\mathrm{F}-O$. mediterranea; $\mathrm{G}-O$. montagui; $\mathrm{H}-P$. platensis; $\mathrm{I}-T$. saltator. Scale bar $=10 \mu \mathrm{m}$.

tromeric C-bands. There are many reports of interspecific genome size differences due to the amount of highly repeated DNA in animals (Rees et al., 1976; Rao \& Rai, 1987; Black \& Rai, 1988). A direct correlation between total DNA content and C-heterochromatic DNA is a general rule for primate species (Manfredi Romanini et al., 1991; Ronchetti et al., 1993): talitroidean amphipods may represent a further example.

In gastropod molluscs, sarcopterygian fish, and amphibians, terrestrial or land-colonising species have markedly larger genomes than related aquatic species (Cavalier-Smith, 1985; Vinogradov, 2000; Vitturi et al., 2005). Assuming that genome size has a selective (adaptive) advantage (Cavalier-Smith, 1985; and references in Gregory \& Hebert, 1999), a large genome is thought to be a pre-adaptive character for terrestrial life, conferring resistance to hypoxia, low energy supply and fluctuations in humidity and temperature, and a lower basal metabolic rate (Shakhbasov \& Ganchenko, 1990; Vinogradov, 1998).

Talitrida is considered to be a monophyletic infraorder (Serejo, 2004 and references therein), and terrestrial and supralittoral Talitridae have evolved from a marine hyalid ancestor (Bousfield, 1984; Friend \& Richardson, 1986; Spicer et al., 1987). Talitridae appear to be endowed with a larger GS than Hyalidae and, assuming an adaptive role of GS, an increase in their amount of nuclear DNA during their evolution might suggest this adaptation to supralittoral and terrestrial life has also occurred in this taxon. As all the talitrids studied are supralittoral species, it would be interesting to extend the cytogenetical analysis to fully terrestrial species [landhoppers of the Group IV according to Bousfield (1984)] to confirm this evolutionary trend. Moreover, the hypothetical hyalid ancestor 
of supralittoral talitrids should have a karyotype of $2 \mathrm{n}=$ 50 median centromere chromosomes, presently shared by all the Talitridae and some Hyalidae. The presence of species characterised by diploid chromosome numbers close to 50 (i.e. $2 \mathrm{n}=48 ; 2 \mathrm{n}=50 ; 2 \mathrm{n}=52$ ) in other families of Gammaridea, such as Gammaridae, Lysianassidae, Metacrangonyctidae, Niphargidae, and Pontoporeidae (Coleman, 1994, and references therein), indicates that these values are not independent, but probably were shared by their respective ancestors, and a $2 n$ value close to 50 is the plesiomorphic condition at the suborder level. Taking this into account, the value $2 \mathrm{n}=22$ in $P$. (P.) schmidti may be considered as a derived (apomorphic) character.

Of particular interest is that, compared to closely related species, both $O$. gammarellus and $A$. prevostii tend to occupy the upper levels of the intertidal or supralittoral zone - with the former sometimes becoming fully terrestrial - (Spicer et al., 1987; Ingólfsson, 1977) and their geographical distribution shifts northwards (Ingólfsson, 1977; Bellan-Santini, 1993; Myers et al., 2007) in locations, where climatic conditions are severe and there are long exposures to air when the tide goes out. $O$. gammarellus and $A$. prevostii have the same karyotype, similar AT-DNA \%, and the largest GS in their respective families. This fact could indicate a correlation between cytogenetical characteristics and environment not only in terms of supralittoral life, but also resistance to frost and cold. A general increase in the DNA amount in polar or sub-polar species vs. those from temperate zones is reported for other amphipods (Rees et al., 2007) and animal taxa, such as fish (Morescalchi et al., 1996) and gastropod molluscs (Battaglia et al., 1992). Moreover, in plants, genome size is correlated with frost resistance (McGillivray \& Grime, 1995).

The present paper is a first attempt to give an insight into the role of cytogenetical characters in the evolution of Talitrida with special reference to their adaptation to supralittoral and terrestrial life. Only a few of the 200 and 110 species of Talitridae (Spicer et al., 1987) and Hyalidae (Bousfield \& Hendrycks 2002), respectively, have been studied karyologically and, therefore, further studies are needed to confirm or contradict the above hypotheses and contribute to a phylogenetic analysis by providing additional characters for phylogenetic tree construction.

ACKNOWLEDGEMENTS. Authors thank G.V. Helgason and the staff of the Sandgerði Marine Centre, University of Iceland, for hospitality and facilities. The visit to the Sandgerði Marine Centre was funded by the EC Improving the Human Potential Programme. Authors are also grateful to S. Ruffo (Natural History Museum, Verona, Italy) for the taxonomical identification of the amphipods and the precious comments that improved the manuscript, and to J. Frankenfield (CNR Institute of Marine Biology, Venice, Italy) for the revision of the English text.

\section{REFERENCES}

Bachmann K. \& Rheinsmith E.L. 1973: Nuclear DNA amounts in Pacific Crustacea. Chromosoma 43: 225-236.
Barnard J.L. \& Karaman G.S. 1991: The families and genera of marine Gammaridean Amphipoda (except marine Gammaroids). Rec. Aust. Mus. (Suppl.) 13: 1-418.

Battaglia B., Bisol P.M., Lazzaretto I., Libertini A., Marcato S., Patarnello T. \& Varotto V. 1992: Studies on genetic differentiation in populations of Antarctic and SubAntarctic marine invertebrates. In: Proceedings of the $2^{\text {nd }}$ Meeting on Antarctic Biology, Padova (Italy) Feb. 26-28 1992. Scienza e Cultura (spec. issue), pp. 121-130.

Bellan-Santini D. 1993: Genus Orchestia. In Ruffo S. (ed.): The Amphipoda of the Mediterranean. Part 3. Gammaridea (Melphidippidae to Talitridae), Ingolfiellidea, Caprellidea. Mém. Inst. Oceanogr., Monaco 13: 742-753.

BLACK W.C. \& RAI K.S. 1988: Genome evolution in mosquitoes: intraspecific and interspecific variation in repetitive DNA amounts and organization. Genet. Res. 51: 185-196.

Bousfield E.L. 1984: Recent advances in the systematics and biogeography of landhoppers (Amphipoda: Talitridae) of the Indo-Pacific region. In Radovsky F.J., Raven P.H. \& Sohmer S.H. (eds): Biogeography of the Tropical Pacific. Bishop Museum Special Publication 72, pp. 171-210

Bousfield E.L. \& Hendrycks E.A. 2002: The Talitroidean Amphipod family Hyalidae revised, with emphasis for the North Pacific fauna: systematics and distributional ecology. Amphipacifica 3: 17-134.

CAvalier-Smith T. 1985. Cell volume and the evolution of eukaryote genome size. In Cavalier-Smith T. (ed.): The Evolution of Genome Size. John Wiley and Sons, Chichester, UK, pp. 105-184.

Coleman C.O. 1994: Karyological studies in Amphipoda (Crustacea). Ophelia 34: 93-105.

Dobigny G., Ducroz J., Robinson T. \& Volobouev V. 2004: Cytogenetics and cladistics. Syst. Biol. 53: 470-484.

FARRIS J.S. 1978: Inferring phylogenetic trees from chromosome inversion data. Syst. Zool. 27: 275-284.

Friend J.A. \& Richardson A.M.M. 1986: Biology of terrestrial amphipods. Annu. Rev. Entomol. 12: 25-48.

Gregory T.R. \& Hebert P.D.N. 1999: The modulation of DNA content: proximate causes and ultimate consequences. Genome Res. 9: 317-324.

INGÓLFSSON A. 1977: Distribution and habitat preferences of some intertidal amphipods in Iceland. Acta Natur. Island. 25: $1-28$.

Ketmaier V., Amendola D., Scapini F. \& De Matthaeis E. 2003: Large scale phylogeography of the landhopper Orchestia cavimana: combining allozymes and mtDNA. In Abstracts of the $11^{\text {th }}$ International Colloquium on Amphipoda. Tunis, Tunisia, 25-30 March 2003. pp. 15-16.

Le Calvez J. \& Certain P. 1951: Gammarus chevreuxi sext. et la caryologie des gammariens. Arch. Zool. Exp. Gen. 88: 131-141.

Levan A., Fredga K. \& Sandberg A.A. 1964: Nomenclature for centromeric position on chromosomes. Hereditas 52: 201-220.

Libertini A. \& Krapp-Schickel T. 2000: Chromosome number and karyotype analysis in eight marine amphipod (Crustacea) species. Pol. Arch. Hydrobiol. 47: 465-471.

Libertini A., Colomba M.S. \& Vitturi R. 2000: Cytogenetics of the amphipod Jassa marmorata Holmes, 1903 (Corophioidea: Ischyroceridae): karyotype morphology, chromosome banding, fluorescent in situ hybridization and nuclear DNA content. J. Crust. Biol. 20: 350-356.

Manfredi Romanini M.G., Formenti D., Stanyon R. \& PellicCIARI C. 1991: C-heterochromatic DNA and the problem of genome size variability in Hominoidea. In Ghiara G., Ange- 
lini F., Olmo E. \& Varano L. (eds): Proceedings of a Symposium on the Evolution of Terrestrial Vertebrates. Napoli, Italy, 9-11 June 1998. UZI Selected Symposia and Monographs 4, Mucchi, pp. 387-397.

McGillivray C.W. \& Grime J.P. 1995: Genome size predicts frost resistance in British herbaceous plants: implications for rates of vegetation response to global warming. Funct. Ecol. 9: $320-325$.

Morescalchi A., Morescalchi M.A., Odierna G., Stingo V. \& CAPRIGLIONE T. 1996: Karyotype and genome size of zoarcids and notothenioids (Teleostei, Perciformes) from the Ross Sea: cytotaxonomic implications. Polar Biol. 16: 559-564.

Myers A., McGrath D. \& King R. 2007: Keys to the North East Atlantic and Mediterranean Amphipods. http://www.amphipoda.com.

Naranjo C.A., Poggio L. \& Brandham P.E. 1983: A practical method of chromosome classification on the basis of centromere position. Genetica 62: 51-53.

Poisson R. \& Le Calvez J. 1948. La garniture chromosomique de quelques Crustacés amphipodes. C. R. Acad. Sci. 227: 228-230.

RAO P.N. \& RAI K.S. 1987: Inter and intraspecific variation in nuclear DNA content in Aedes mosquitoes. Heredity 59: 253-258.

Rees D.J., Dufresne F., Glémet H. \& Belzile C. 2007: Amphipod genome sizes: first estimates for Arctic species reveal genomic giants. Genome 50: 151-158.

Rees R.W., Fox D.P. \& MAher E.P. 1976: DNA content, reiteration and satellite in Dermestes. In Jones K. \& Brandham P.E. (eds): Current Chromosome Research. North-Holland Publications, New York, pp. 33-41.

Ronchetti E., Crovella S., Rumpler Y., Pellicciari C. \& ManFREDI RoMANINI M.G. 1993: Genome size and qualitative and quantitative characteristics of $\mathrm{C}$-heterochromatic DNA in
Eulemur species and in a viable hybrid. Cytogenet. Cell. Genet. 63: 1-5.

Ronchetti E., Salvadori S. \& Deiana A.M. 1995: Genome size and AT-content in Anguilliformes. Eur. J. Histochem. 39: 259-264.

Serejo C.S. 2004: Cladistic revision of talitroidean amphipods (Crustacea, Gammaridea), with a proposal of a new classification. Zool. Scripta 33: 551-586.

Shakhbasov V.G. \& Ganchenko A.V. 1990: Nonspecific tolerance and DNA content in genome of amphibians. Dokl. Akad. Nauk SSSR 314: 971-975 [in Russian].

Siter J.I., Moore P.G. \& TAYlor A.C. 1987: The physiological ecology of land invasion by the Talitridae (Crustacea: Amphipoda). Proc. R. Soc. Lond. (Biol.) 232: 95-124.

STEPHENSEN K. 1940: Marine Amphipoda. Zoology Iceland 3: $1-111$.

SUMNER A.T. 1972: A simple technique for demonstrating centromeric heterochromatin. Exp. Cell. Res. 75: 304-306.

Tafani B., Ugolini A., Bazzicalupo M., Mengoni A. \& Ruffo S. 2004: Phylogenetic relationships among Mediterranean sandhoppers. J. Nat. Hist. 38: 499-508.

Tiersch T.R., Chandler R.W., Wachtel S.S. \& Elias S. 1989: Reference standards for flow cytometry and application in comparative studies of nuclear DNA content. Cytometry 10: 706-710.

Vinogradov A.E. 1998: Genome size and GC-percent in vertebrates as determined by flow cytometry: The triangular relationship. Cytometry 31: 100-109.

Vinogradov A.E. 2000: Larger genomes for molluskan land pioneers. Genome 43: 211-212.

Vitturi R., Libertini A., Sineo L., Sparacio I., Lannino A. \& Colomba M.S. 2005: Cytogenetics in the land snails Cantareus aspersus and C. mazzullii (Mollusca: Gastropoda: Pulmonata). Micron 36: 351-357.

Received May 15, 2007; revised and accepted August 30, 2007 